\title{
JUURNAL.RU
}

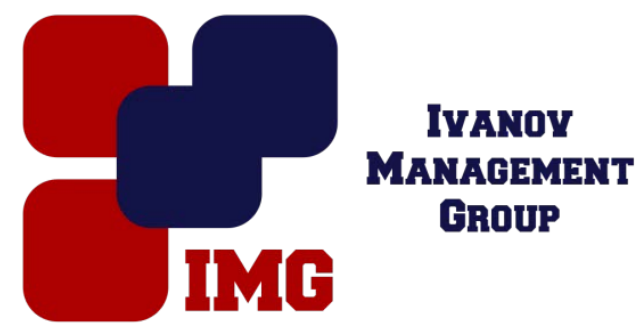

Литвинцева М.Б.

doi: 10.18411/lj-28-02-2017-4-01

idsp 000001:lj-28-02-2017-4-01

\section{«Сравнительный анализ исторических парковых комплексов Санкт- Петербурга и Пекина как исторических и культурных центров»}

\section{Аннотация}

В статье рассматриваются национальные особенности исторических парковых зон городов Санкт-Петербурга и Пекина. Проводится сравнительный анализ по критериям: ценовой фактор; возраст; площадь парка; местоположение.

Исторические парковые комплексы имеют несомненную историкокультурную ценность и являются объектами культурного наследия, в которые входят памятники истории и архитектуры, и окружающая их природная среда, образуя особые экологические зоны. Это обуславливает актуальность изучаемой темы в самых различных сферах науки и социальной жизни: образовании [1], туризме [2]. Несмотря на различия в возрасте и художественных решениях парковых комплексов, возникает целый ряд проблем и задач - единых для всех исторических комплексов-парков мира. На всех этапах истории человечества в основе подходов и методов формирования парковых комплексов лежат экологические принципы. Особое значение эти территории приобретают в условиях резкого усиления негативного влияния человечества на природу и обсуждения вопросов социального «вреда и пользы» [3]. В первую очередь это относится к промышленному освоению территорий, росту городов.[4]

В условиях постоянного роста численности населения городов изменяется экологическое пространство. В крупных мегаполисах, таких как Санкт-Петербург и Пекин, основную нагрузку испытывают ближайшие пригороды. Многочисленные жилые застройки, автодороги, коммуникации привели к изменению экологической остановки в городах и пригородных территориях. Площадь городов стремительно возрастает, и в будущем интенсивность этого процесса будет только увеличиваться. Возможно, не вполне корректным будет сравнение Пекина, города ведущего свою историю с 473 года, занимающего

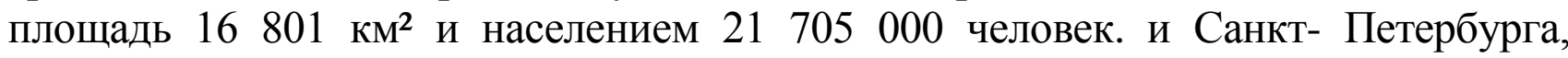


основанного Петром I 27 мая 1703 года, где на площади 1439 км² $^{2}$ проживает 5 225690 человека. Однако оба эти удивительные по красоте мегаполиса, явления национальной и мировой культуры, города объединяющие историю и современность.

Санкт-Петербург стал первым русским городом, выстроенным с использованием лучших достижений европейского градостроительства и архитектуры. Это город, который почти с самого дня своего основания стал развиваться по заранее разработанному плану, что определило высокий градостроительный уровень и способствовало формированию городских ансамблей, характерныX для конца XVIII, начала XIX вв. Архитектурное великолепие бывшей имперской столицы позволило включить Исторический центр Санкт-Петербурга как целостный объект в список культурного наследия ЮНЕСКО.

В Китайской Народной Республике в списке объектов Всемирного наследия ЮНЕСКО значатся 50 наименований (на 2016 год), в их числе Центральная ось Пекина (включая Бэйхай).

Конечно, эти и другие исторические объекты формировались в рамках иного временного периода, они являются элементом той социальной среды и в наши дни утратили своё первоначальное назначение. Исторические парки, создававшиеся как приусадебные комплексы или резиденции правящей элиты, в настоящее время являются рекреационными территориями, которые активно посещаются как горожанами, так и туристами.[5]

Садово-парковые архитектурные ансамбли Китая обладают гибкой концепцией. Сад в Китае строится так, чтобы достичь в нем баланса, гармонии, пропорций и разнообразия, лежащих в основе жизни, гармонии Человека и Природы. Архитектурный садово-парковый ансамбль отвечает всем законам природы и даже превосходит их. Красота природы стоит на главном месте. [6]

В настоящее время Пекин представляет собой «визитную карточку» Китая, ведь именно по нему судят о стране в целом. Да что тут говорить, Пекин мировой мегаполис, культурный, экономический, политический, а в последнее время популярный туристический центр; город объединяющий историю и современность, западное и традиционно китайское [7].

За свою многовековую историю город много раз переживал периоды расцвета и застоя. Начиная с 1949 года, является официальной столицей Китая. Население города стремительно растет, требуя все новых построек для расселения людей. Бурный промышленный рост принес множество проблем связанных с перенаселением. Однако нужно отдать должное архитекторам, они сумели связать воедино современные постройки, с традиционно китайским стилем. Нельзя не отметить и тот факт, что стремительное развитие, к сожалению, привело в том числе и к достаточно серьезным проблемам, в частности, в сфере экологии. Сегодня город является довольно частым свидетелем такого явления, как смог, а сами пекинцы достаточно интенсивно жалуются на отвратительное качество воды. По словам директора департамента городского планирования Пекина, профессора 
Пекинского муниципального института городского планирования и дизайна Фэнг Фей Фей- «Пекин однажды ради расширения территории повредил экологическую и культурную систему вокруг города. Было поглощено и испорчено множество маленьких городков с богатой культурой и историей. Перед расширением города надо обязательно сначала позаботиться о сохранении микроклимата территорий, на которые оно приходится. Пекину сейчас уже не исправить эти ошибки, но другие могут учиться на них» [8]

Пекин знаменит своими парками. Их много - старинных и современных, с историческими постройками и без таковых. Отличительная черта пекинских парков - их ухоженность. Кроме того, в парках вы увидите людей, которые танцуют, поют, играют на музыкальных инструментах, рисуют, занимаются цигун и тайцзицюань и др. Это характерно и для Китая в целом. Выйдя на заслуженный отдых, китайцы активно стремятся наверстать упущенное ранее время на отдых. По мнению китайцев, в тройку самых популярных занятий китайских пенсионеров попали игра в шахматы, в мацзян, коллективные танцы. Здесь важно психологическое ощущение востребованности и общности с другими пенсионерами.

Как показывает анкетирование, проведённое в Пекине, около $80 \%$ городских пенсионеров участвуют в оздоровительных спортивных мероприятиях хотя бы три раза в неделю. Из оставшихся $15 \%$ физически не могут принимать участие в спортивных встречах. То есть в Китае абсолютное большинство пенсионеров регулярно тренируются в меру своих возможностей, как минимум совершая пешие прогулки в парках и близ водоёмов. [9]

В России до начала XVIII века (правление Петра I) садово-парковая архитектура не рассматривалась как отдельный вид искусства. В начале восемнадцатого века молодой царь Петр I решил превратить патриархальную Россию в «европейскую» империю. В 1703 году в устье Невы была заложена новая столица, Санкт-Петербург, в соответствии с последними европейскими принципами градостроения и фортификации. Впервые в русском градостроительстве появилась регулярность, известная в Европе с начала XVII века. Одним из первых регулярных садов петровской эпохи стал Петергоф, построенный в честь военной славы зарождающего русского флота. «Визитная карточка» Петергофа фонтан «Самсон, раздирающий пасть льва», стоящий в центре Большого каскада, напоминает о победе русской армии над войсками шведского короля Карла XII в Северной войне. Большой каскад начинается от дворца и переходит в главный канал, который через парк «врезается» в Балтику, символизируя прорыв России в Европу. Сад - четыре сектора, разделенные крестообразно расположенными аллеями - также выполнен в голландском стиле. Главное его украшение - это фонтаны. У западной границы парка расположен Марлинский ансамбль. Здесь находятся сады Венеры, в центре которого стоит ее мраморная статуя, по границам - подпорные стенки с нишами и вазами, фигурные лестницы, балюстрада и беседки.[10] 
В XVIII веке в России создаются первые в мире публичные сады. Одним из них стал знаменитый Летний сад в Петербурге. Он был разбит по образцу регулярных садов - с симметрично расположенными аллеями, фигурной стрижкой деревьев и кустарников, партерными цветниками, декоративной скульптурой, фонтанами. В петровское время он являлся парадной царской резиденцией, где в летнее время протекала общественная и придворная жизнь Петербурга. В петровские времена в Летнем саду был птичник, изящная беседка, дом с фонтанным снарядом, приводимым в движение по средству большого колеса, а рядом с ним зверинец. Была большая оранжерея с экзотическими цветами. В центре парка располагался водоем, выложенный плиткой, и гротом, из которого бил фонтан.

В последующие годы отпечаток на облик Петербурга и его окрестностей наложило увлечение Екатерины II английскими пейзажными садами, служившими тем образцом, который императрица пыталась воссоздать и в своей царскосельской резиденции, которая в настоящее время входит в список Объектов Всемирного наследия ЮНЕСКО. Вскоре после восшествия на престол Екатерина стала нанимать на службу британских садовых мастеров и посылать на учебу в Британию русских садовников и архитекторов. [11]

В настоящее время по данным Геоинформационной системы СанктПетербурга на территории города имеется 483 объекта зелёных насаждений, входящих в состав объектов культурного наследия. Из них 100 объектов обозначены как «парки» (далее - исторические парки). В Санкт-Петербурге минимальный размер территории существующего исторического парка - 0,54 га, максимальный - 513 га. Однако 90\% исторических парков имеют площадь более 4 га, примерно 60\% - более 10 га. С другой стороны, часть объектов, обозначенных в перечне объектов культурного наследия как «сад», также имеют площадь от 4 до 14 га.

Как известно, парки являются сердцем мегаполиса и играют важную роль в жизни горожан. Это места, где люди могут проводить свободное время, общаться, отдыхать от городской суеты и просто наслаждаться природой. Парковые зоны способствуют улучшению качества воздуха и являются средой обитания различных представителей флоры и фауны. Также они способствуют сплочению городского населения и повышению качества его жизни, что соответствует духовным основам хозяйственной культуры [12].

Нино Татунашвили проводя сравнительно-конкурентный анализ парков, считает одним из основных критериев сравнения, такой показатель как посещаемость. Автор определяет следующие факторы, влияющие на посещаемость: ценовой фактор; возраст; площадь парка; местоположение.[13]

По данным статистических наблюдений за посещаемостью парков оказалось, что в первой половине дня в основном их посещают пожилые люди, часть из них с детьми дошкольного возраста. Вечером парк посещают преимущественно молодые и среднего возраста люди, чтобы отдохнуть от суеты рабочего дня, насладиться тишиной и приблизиться к природе. 
Ценовой фактор определяет степень доступности парка для разных социальных групп. Платный вход, доход от которого направляется на содержание парка и благоустройство территории, и в Санкт- Петербурге и в Пекине является дифференцированным. Так, например, для посещения паркового комплекса в Петергофе взрослому гражданину России нужно заплатить 450 рублей, иностранному гражданину посещение обойдется в 600 рублей. Посещение Екатерининского дворца и парка будет стоить 700 рублей независимо от национальности. Цена будет существенно отличаться для пенсионеров, студентов, детей и т.д. и составит 200 рублей. Приятно удивляет Летний сад, открытый после реконструкции в 2012 году, мраморные скульптуры начала XVIII века заменены на копии, выполненные из современных искусственных материалов, его посещение ничего не будет вам стоить.

В тоже время посещение паркового комплекса Храм Неба в Пекине для иностранца будет стоить 15 юаней (150 рублей), храмового комплекса 35 юаней (350 рублей). Пожилые китайцы могут осмотреть достопримечательность и отдохнуть в парке бесплатно. Льготами могут воспользоваться дети ростом до 120 сантиметров.

Цена различается кроме того по так называемой «сезонности». Для Пекина в высокий сезон с 1 апреля по 31 октября цена выше на 5 юаней. Для СанктПетербурга высокий сезон продолжается с 25 апреля по 25 октября, в остальное время посетить многие исторические парковые комплексы возможно даже бесплатно. В высокий сезон, с 1 апреля по 31 октября, в парковый комплекс Бэйхай входной билет будет стоить 20 юаней (200 рублей), в парк 10 юаней (100 рублей). В остальное время стоимость билетов составляет 15 юаней (150 рублей), только в парк 5 юаней (50 рублей).

Возраст парка как сравнительная характеристика очень важен. Парки, давно существующие обладают историческим потенциалом, традициями, что является дополнительным «стимулом» для посетителей.

Достопримечательности «Северной» столицы существенно моложе китайских. Дворцово-парковый комплекс Петергоф был заложен Петром I в 1712 году, как дворцово-парковый ансамбль, формировался на протяжении XVIII начала XX века, и как музей открылся в 1918 году. Строительство Екатерининского дворцового комплекса началось в 1717 году, в течение XVIII века неоднократно перестраивалось. В советское время во дворце открылся музей.

Таким образом, основная масса исторических дворцово- парковых ансамблей Санкт- Петербурга ведет свою историю с начала XVIII века, открылись для свободного посещения после Великой Октябрьской революции, сильно пострадали во время Великой Отечественной войны, затем полностью восстановлены реставраторами.

Парковый комплекс Бэйхай был заложен в X веке. Парк сильно пострадал в результате действий Альянса восьми государств в 1900 году, и долгие годы находился в запустении. До 1911 года, будучи частью императорского города, он был недоступен для посещения. Его открыли для публики в 1925 году. После 
образования КНР в 1949 году на его территории были проведены широкомасштабные реставрационные работы. Сейчас парк Бэйхай входит в число самых посещаемых мест Пекина, ежегодно привлекая миллионы китайских и иностранных туристов. Коренные пекинцы также любят проводить здесь время.

Храм Неба был возведен в 1420 году, также пострадал на рубеже XX века, превратившись в развалины, большая часть наследия была уничтожена и украдена. В 1918 году признан Национальным достоянием и был открыт как музей. Подобное сохранение традиционной материальной культуры - важный аспект социальной жизни китайцев [14], в том числе как элемент идентификации себя в режиме «свой-чужой» [15]. Находится под покровительством ЮНЕСКО, как объект мирового наследия.

Из вышеизложенного следует, что исторические парковые комплексы Пекина хоть и старше, однако открылись для публики и подвергались реставрации примерно в одно время с российскими, то есть имеют примерно один возраст.

В современных условиях при росте посещаемости исторических парковых зон, расширении их функционального содержания, увеличение технических возможностей конструирования разнообразных устройств и приспособлений для отдыха, несомненно, важен такой критерий как площадь парка. Так, например, парковая площадь дворцово-паркового комплекса Петергоф 414,2 га, ежегодно его посещают четыре с половиной миллиона человек.

На территории Екатерининского и Александровского парков общей площадью 300 гектаров расположено более сотни архитектурных сооружений: от величественных дворцов и мраморных монументов до многочисленных павильонов, мостиков, придающих паркам неповторимый характер.

Площадь паркового комплекса Храм Неба около 270 га, она обнесена внешней стеной, которая охватывает всю территорию храма протяженностью 6625 метров, внутренняя стена окружает храм и составляет 5287 метров.

Парк Бъэйхай имеет площадь более 69 гектаров, озеро Бэйхай занимает более половины территории парка. В центре парка на 32 м возвышается остров Цюнхуа, где находится Бай Та (Белая ступа) - 40-метровая ступа, сделана из белого камня.

Оценим транспортную доступность рассмотренных выше культурноисторических объектов. Поскольку Храм Неба и Бэйхай находятся на центральной оси Пекина, то добраться до них не составит труда, самый простой и дешевый способ это общественный транспорт (метро, автобус, троллейбус). Поездка, на которых Вам обойдется соответственно: метро- 2 юаня (20 рублей), автобус и троллейбус- 1 юань (10 рублей). При современных темпах метростроения в Пекине добраться до удаленных достопримечательностей становится все проще. Например, если в 2010 году добраться до Летнего дворца императора, парк Ихэюань представляло для иностранца некоторую сложность, то с открытием 4 ветки Пекинского метро поездка от центра займет около 40 минут и обойдется в 2 юаня (20 рублей). 
В Санкт-Петербурге добраться до Летнего сада возможно также городским общественным транспортом: стоимость поездки на автобусе, трамвае обойдется 40 рублей, на метро 36 рублей. До Петергофа, находящегося на расстоянии 26 километров от Санкт-Петербурга придется добираться с пересадками: сначала на метро до остановки маршрутных автобусов или вокзала. Стоимость поездки на электропоезде 55 рублей, поездка займет у вас 30 минут, затем пешком 20 минут. На маршрутном автобусе Вы будете добираться 30 минут за 70 рублей. До Екатерининского дворца и парка, находящегося в городе Пушкин, можно доехать за 36 рублей, потратив на дорогу полчаса.

Исходя из вышеизложенного, можно сделать следующий вывод: добираться до достопримечательностей в Пекине, даже удаленных от центра города удобней и дешевле.

Проведя сравнительный анализ исторических парковых зон городов СанктПетербурга и Пекина, можно сделать вывод, что между ними много общего: их возраст как музеев, дифференцированные цены для разных социальных групп, необходимая транспортная инфраструктура, обширные площади. И все они выполняют одну первостепенную задачу - это «легкие» мегаполиса. Ведь парки в целом, а исторические - в особенности, оказываются важны не только для обеспечения рекреационных потребностей населения, но и для сохранения относительно крупных «островков» окружающей природной среды, оздоровляющих экологическую обстановку в городе. Исторически сложившаяся практика показывает, что предназначение парков состоит в первую очередь, в обеспечении контакта посетителя с «природой» - так, как понимали этот контакт в разные эпохи и в разных странах. Исторические парковые зоны так же создают условия для познавательного и содержательного отдыха жителей города и туристов. 


\section{Литература}

1. Кремнёва Т.А., Ван Ланьцзюй. Китайский язык. Начальный уровень. Иркутск, 2015. $180 \mathrm{c}$.

2. Макеева С.Б. Анализ потенциально-туристских районов КНР // Сборники конференций НИЦ Социосфера. 2012. № 36. С. 16-18.

3. Кузнецова О.В. Что полезно одному, то вредно другому // Вестник Иркутского государственного лингвистического университета. 2004. № 3. С. 46-52.

4. Материалы научно-практической конференции «Исторические объекты садовопарковой архитектуры и экология пространства», 18 мая 2011 г. / под ред. А. С. Владыченский Г и др.7. М., 2011.95 с.

5. Поэзия садов: к семантике садово-парковых стилей. Сад как текст. - 3-е изд., испр. и доп. - М.: Согласие: ОАО «Тип. "Новости"», 1998. - 471 с.

6. Чжан Вэй. Садово-парковая архитектура Китая. Международное радио Китая. http://russian.cri.cn/chinaabc.

7. Терехова Н.В. Американская массовая культура в китае: за и против // Философия и будущее цивилизации: Тезисы докладов и выступлений IV Российского философского конгресса. 2005. С. 409-410.

8. Резник И. Е. Москва может учиться на ошибках Пекина // Зеленый мир. 2013. 03 декабря.

9. Струкова П. Э. Пенсия как песня //Магазета. 2016. 15 января.

10. Кальницкая Е. Я. Петергоф- государственный музей заповедник. ГМЗ «Петергоф». http://peterhofmuseum.ru.

11. Марголис А. Д. Царскосельский коттедж. Дача великого князя Бориса Владимировича. СПб., 2009

12. Кобжицкая О.Г. Духовные основы хозяйственной культуры // Диссертация на соискание ученой степени кандидата философских наук / Иркутский государственный университет. Иркутск, 1999. 210 с.

13. Татунашвили Н.Г. Сравнительно-конкурентный анализ парков культуры и отдыха (ПКиО) г. Москвы. http://tatunashvilini.livejournal.com/4935.html.

14. Кремнев Е.В. Традиционные аспекты современной управленческой культуры государственных служащих КНР // Вестник Забайкальского государственного университета. 2006. № 4. С. 137-141.

15. Адилханян Н.Л. Образ «чужого» в сознании древних китайцев на материале «Каталога Заморья» трактата «Шань хай цзин» // Азиатско-тихоокеанский регион: Диалог языков и культур: Материалы II Международной научно-практической конференции. 2016. С. 19-25.

16. Нагибина И. Ю., Журова Е. Ю. Значение парковых зон для жителей городской среды // Молодой ученый. - 2014. - №20. - С. 84-85.

17. Малахова Татьяна Ивановна. Философский анализ садово-парковой культуры: диссертация ... кандидата философских наук: 24.00.01.- Ростов-на-Дону, 2001.- 131 с.: ил. РГБ ОД, 61 02-9/67-3. 